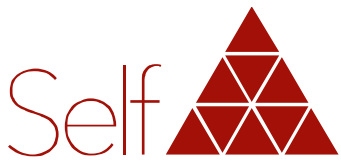

Revista do Instituto Junguiano de Säo Paulo

\title{
A alma, o antigo e o novo
}

\section{The soul, the ancient and the new}

\section{El alma, el antiguo y el nuevo}

que é a alma? $\bigcirc$ que é essa experiência por meio da qual e "dentro" da qual temos sensações, sentimos, pensamos, intuímos, amamos, sofremos, vivemos? $\bigcirc$ que é isso que chamamos todos os dias de "eu", mas que também - lá no fundo - percebemos que é mais do que aquilo que conseguimos apreender a respeito de nós mesmos, ou seja, mais do que o "eu"? Diuturnamente nos relacionamos com e experimentamos nossa própria existência: por vezes isso é bom, outras vezes nem tanto.

Penso nas narrativas acerca da alma - psique ou mente, para quem se sente mais confortável com esses termos - como um "contando e escrevendo histórias". Muitas histórias para contar uma história maior, sendo esta composta de histórias curtas, longas, encadeadas, descontínuas... Não me sinto presa da fantasia de sermos capazes de qualquer outra coisa que não seja descrever a realidade. Minha hipótese é que as formas narrativas que usamos podem se conversar mutuamente e talvez possam ser integradas: a mitológica-religiosa, a poética-literária, a filosófica e a científica, pois que todas são produtos da alma.

Nossa experiência subjetiva varia de qualidade, de intensidade e pode ser (mais ou menos) percebida por meio do olhar introspectivo para dentro de si, mas é essa experiência subjetiva que chamamos de alma. Alguns de nós a chamam de mente. Outros a chamam de psique. Outros (que triste!) de atividade cerebral.

Alguns acham que ela é somente nossa consciência. Nós, junguianos, cremos que haja uma dimensão inconsciente dessa experiência e que esse componente inconsciente seja incomensuravelmente maior e muito mais profundo e ancestral do que a experiência consciente. Seja como for, a alma é a experiência de ser e de existir, a experiência de estar vivo e, no nosso caso (o caso dos seres humanos - as pessoas), a experiência de perceber conscientemente a própria experiência, a partir de uma relação com nosso 
mundo interno, nossos pensamentos, nossos sentimentos, nossas sensações e, seja lá como isso se manifeste em cada um, nossas intuições.

Alguns de nós acreditam que a alma (psique ou mente) seja algo imaterial e, por isso, não se constitua de partículas e átomos como tudo aquilo que percebemos como material (as coisas e o nosso próprio corpo). Acreditam que o corpo e a mente sejam "entidades" distintas e separadas. Muitos desses creem ainda que essa alma imaterial seja imortal, eterna - e divina. Outros pensam que não existe essa separação, que a alma (psique ou mente) e a existência biológica (a vida) sejam inseparáveis e, de fato, a mesma coisa.

Mas o que ninguém contesta é que o nosso corpo e as coisas do mundo só podem ser percebidas por meio da alma, seja lá o que ela for ou de que modo ela seja chamada. Mais do que isso: a alma só pode ser percebida por meio da alma, pois a alma é ela mesma "aquilo" que percebe e, nesse processo puramente subjetivo, a única objetividade possível é dada exclusivamente pelo outro e por sua descrição.

Cada um de nós somente elabora e se relaciona com as suas próprias descrições da realidade, e tem somente a realidade narrada por outros (mitos, ficções, teorias filosóficas, teorias científicas) como contraponto a sua própria subjetividade individual. Assim, temos apenas as histórias contadas por outros para comparar com a nossa própria a cada momento. $E$ sabemos, por experiência, que nossa narração da realidade nunca corresponde completamente àquela existência que vivenciamos e que chamamos de alma. Toda realidade é uma realidade descrita, uma história contada, uma teoria. Um fato nunca é de fato um fato, mas sempre e tão somente a descrição de um fato experimentado.

Nós, seres humanos, somos parte de uma longa cadeia evolutiva de transformações da matéria que se iniciou com o próprio começo do universo (ou pelo menos, deste universo que conseguimos observar), passou pelo surgimento da vida na Terra (e é bom deixar claro desde já que - do mesmo modo que em relação à alma - não sabemos o que é isso que chamamos de vida e também não sabemos o que é isso que chamamos de matéria) e chegou até ao nosso próprio surgimento na África há cerca de 200 mil anos. De lá para cá nós readquirimos o controle do fogo (antes de nós, pelo menos dois ou três dos nossos primos evolutivos já haviam conseguido produzir o fogo), passamos a enterrar nossos mortos (alguns primos evolutivos também o fizeram independentemente de nós), começamos a produzir esculturas, a pintar no fundo das cavernas e a construir templos megalíticos, domesticamos plantas e animais, passamos a viver em cidades, inventamos a escrita e construímos a civilização.

Certamente devemos isso ao crescimento evolutivo do cérebro, mas esse acontecimento sozinho não pode explicar tudo o que somos ou, pelo menos, - que nos tornamos. De fato, parece que ao tentarmos explicar os fenômenos - incluindo nossa existência -, meramente por meio da sua constituição estrutural, talvez não sejamos suficientemente compreensivos: 
atribuímos níveis de complexidade diferentes para a matéria, para a vida e para a psique, cada um desses níveis representando o novo na existência em relação ao anterior.

Buscamos significado para o que somos. Nossas histórias de ser e de existir são histórias de atribuição de significados: sobre como precisamos encontrar significado nas coisas e nos acontecimentos, sobre como somos acometidos por uma necessidade imperiosa, incoercível, de atribuir significado a nossa própria existência e à existência do mundo, atormentados pela necessidade de buscar um significante (ou grupo de significantes) que assuma o lugar e o valor de imagem ou ideia ou experiência de Deus. A imagem, ideia ou experiência de Deus - em qualquer uma de suas formas - é o significante por excelência e se revela tanto nas religiões quanto na atitude narrativa subjacente ao racionalismo matemático. Pode-se encontrar, invariavelmente, em todas as descrições da realidade, um argumento externo, um significante exterior ao sistema de pensamento com valor de imagem ou ideia ou experiência de Deus: eis a base de todas as descrições da realidade.

Nossa experiência subjetiva (alma, psique ou mente) é marcada por uma pulsão para criar e vivenciar uma ou várias imagens ou ideias ou experiências de Deus destinadas a dar significado e sentido à vida e à morte. Essa pulsão para formular tais ideias, imagens ou experiências de Deus possui caráter universal e inato e é "instinto" psíquico exclusivamente humano: aquilo que Jung chama de Self ou si-mesmo, o arquétipo central da existência humana. Nenhum outro ser vivo elabora perguntas a respeito da existência ou pensa e reverencia Deus ou os deuses. Geramos imagens ou ideias ou experiências de Deus em uma diversidade potencialmente infinita de expressões, expressões estas exclusivamente humanas, que resultam sempre em visão de mundo e narrativas da realidade.

E "visão de mundo" é a narrativa acerca da realidade que contamos a nós mesmos, aquela que nos justifica diante de nós mesmos. Essa visão de mundo gera e é gerada pelas histórias de ser e de existir de cada um de nós, mesmo que cada um pareça meramente expressar uma coleção ou conjunto de formas de funcionamento e comportamentos coletivos, conscientes ou inconscientes. Ou seja, nossa visão de mundo é sempre particular e peculiar, mesmo que invariavelmente constituída por elementos universais e coletivos; ela pode assim ser chamada de alma, por se constituir de tudo o que nos precede e nos estrutura e do novo na existência que cada um de nós representa.

Ricardo Pires de Souza

Editor científico 